THURSDAY, JANUARY Io, 1878

\section{THE SALARIES OF THE OFFICERS IN THE BRITISH MUSEUM}

THE inadequacy of the salaries of the officers of the British Museum has long been a standing grievance. It is manifestly impossible to give any valid reasons why the literary and scientific men of this great national establishment should not receive emoluments at least equal to those granted in the ordinary branches of the Civil Service. The obstinacy of the trustees in clinging to obsolete principles of priority, and in endeavouring to keep entirely in their own hands the right of nomination to all the more important posts, has, no doubt, been the main cause why the Treasury have until recently refused to do justice to a most meritorious and ill-treated branch of the public service. From the "Correspondence between the Trustees of the British Museum and the Treasury," which has lately been issued as a Parliamentary Paper, we are glad to find that in this instance, as on former occasions, the present Ministry has been induced to do justice where their predecessors in office have persistently ignored righteous claims. After a long correspondence, commenced in May, 1876 , and extending over some fifteen months, it seems to have been finally settled that the salaries of the keepers of the various departments shall be raised to $750 l$. per annum affer five years' service, instead of stopping at $600 l$., the former limit, and that the salaries of the assistant-keepers shall rise to $600 l$. after five years' service, instead of being restricted to $450 \mathrm{l}$. as heretofore. The assistants in the various departments will, in future, be divided into two classes, the first, or upper class, with salaries commencing at $250 l$. per annum, and rising by annual increments of $15 l$ to $450 l$.; those of the second, or lower class, commencing at $\mathrm{x} 20 \mathrm{l}$, and rising by increments of $10 \mathrm{l}$. to $24,0 \%$. This will create a considerable general improvement in the position of these subordinates, of whom the junior assistants, as they are called, have hitherto commenced at $90 l$, and the senior assistants have never risen beyond $400 l$. But the trustees have agreed to regard the new second class for the future as an "educational class," from which those persons who show special aptitude for the work of the $\mathrm{d}$ fferent departments may be promoted to the first class, whilst those who have no extraordinary abilities must remain content with the maximum salary of the lower class. Another concession that the trustees have been compelled to make in order to obtain the above-mentioned advantages is a reduction in the number of the assistants of the upper class. The Treasury justly point out to the trustees that the scheme of having a first class of assistants double the number of that of the second class, is "inconsistent with all ordinary classification," and that the comparative numbers of the two classes "ought "to be exactly reversed." This the trustees have, as it appears, somewhat unwillingly undertaken to effect, by a gradual reduction of the number of first-class assistants as vacancies occur, and by making all future appointments into the second class, except when "an opportunity occurs of securing the services of a person possessing very special qualifications."
A third point which the trustees "are prepared to re. consider" is the number of keeperships, now amounting to thirteen, and in order that the Treasury may have greater control in this matter, they have undertaken not to fill up any keepership which may hereafter become vacant, "without the previous concurrence of the Trea. sury." A still more important proposal made by the Treasury and "conceded by the trustees," is that the position of keeper should be considered as a "staff appointment, to which no officer within the Museum should have any right of succession by seniority." This "concession" will, we trust, do away with the practice of putting round men into square holes, in order to $c b t_{2} ;$; for them an additional salary, which in former years ha , we fear, been followed in some instances at the Britis!i Museum.

One remaining point, which has much exercised the well-known economy of the Secretary of the Treasury, we are pleased to see he has been obliged to give up. It was proposed that the keepers who occupy the residences attached to the British Museum ought to give up a certain portion of their salaries in lieu of rent. In reply to this in. genious suggestion, the trustees very justly urge that those keepers who reside on the premises have important duties to perform, in having to take in turn the general charge of the whole museum under the principal librarian, for which the accommodation of a residence is no more than a fair equivalent. This contention was ultimately allowed to prevail, and on the whole, we think, there is every reason to be grateful to the Government for the improvements effected by the new scheme in the position of the employes at the British Museum. Even in these hard times it cannot be said that a place of $750 \mathrm{l}$. per annum with a good residence attached and a pension in future when work is no longer possible, is not such a prospect as may well attract some of the cleverest youths of the period who have a leaning towards literature or science to seek the place of "junior assistant" in the British Museum.

\section{FULES VERNE}

Hector Servadac, or the Career of a Comet.-From the Earth to the Moon.-Around the Moon.-Twenty Thousund Leagues under the Sea.-Around the World in Eighty Days. - The Fur Country.-A Winter amid the Ice, \&c., \&c. (London: Sampson Low and Co.)

THESE remarkable works, which we owe to the genius of Jules Verne, the first-named being that which has last appeared, are well deserving of notice at our hands, for in the author we have a science teacher of a new kind. He has forsaken the beaten track, bien entendu; but acknowledging in him a travelled Frenchman with a keen eye and vivid imagination-and no slight knowledge of the elements of science-we do not see how he could have more usefully employed his talents. He will at once forgive us for saying that when we compare his romances of the ordinary type, such as "Martin Paz," with those we have given above, we think that he, as well as his readers, is to be congratulated upon the new line he has opened out.

There have been many books before his time in which the interest has centred in some vast convulsion of nature, or in nature generally being put out of joint, but in these 